\author{
SUPPLIER RELATIONS AND \\ ADOPTION OF NEW TECHNOLOGY: \\ RESULTS OF SURVEY RESEARCH \\ IN THE U.S. AUTO INDUSTRY
}

Susan Helper

Working Paper 5278

\author{
NATIONAL BUREAU OF ECONOMIC RESEARCH \\ 1050 Massachusetts Avenue \\ Cambridge, MA 02138 \\ September 1995
}

This paper is part of the NBER's project on Industrial Productivity and Technical Change. Many thanks to Albert O. Hirschman, Martin Feldstein, Maryellen Kelley, Charles Sabel, Bo Carlsson, Bennett Harrison, James D. Adams, Amresh Hanchate, Richard Parkin and David I. Levine for comments; to Patrick Coburn and Vitaliy Khizder for excellent research assistance; and to the Sloan Foundation, the Ameritech Foundation, the Center for Regional Economic Issues at Case Western Reserve University, and the MIT International Motor Vehicle Program for financial support. This paper is part of NBER's program in Productivity. Any opinions expressed are those of the author and not those of the National Bureau of Economic Research.

(C) 1995 by Susan Helper. All rights reserved. Short sections of text, not to exceed two paragraphs, may be quoted without explicit permission provided that full credit, including $(-$ notice, is given to the source. 


\title{
SUPPLIER RELATIONS AND \\ ADOPTION OF NEW TECHNOLOGY: \\ RESULTS OF SURVEY RESEARCH \\ IN THE U.S. AUTO INDUSTRY
}

\begin{abstract}
Using an original data source, this paper investigates the circumstances under which firms adopt computer numerical control (CNC), an important type of flexible automation which can significantly increase productivity, product variety and quality. The paper shows that arms'length supplier/customer relationships are a significant barrier to CNC adoption, even where CNC would improve efficiency. For firms where $\mathrm{CNC}$ would be efficient, but who currently receive little commitment from their customers, an increase in contract length of one year would increase the adoption rate by $30 \%$.

These results have theoretical implications in two areas. First, the paper integrates questions of appropriability into the technical change literature, by adding supplier relations as a determinant of technology adoption. Second, the paper extends transaction-cost analysis, by relaxing the assumption that agents' private maximizing behavior will always produce organizational forms that maximize social efficiency.
\end{abstract}

\section{Susan Helper}

Department of Economics

Case Western University

Cleveland, $\mathrm{OH} 44106$ 
An economy is not affected in any material way by new technology until the use or ownership of that technology is widespread.

$$
\text { Stoneman (1983, p.65) }
$$

By now the tale of an invention made in the US but reaching its full potential only in other countries is an oft-told one: it is true for both product innovations (such as the VCR, the microwave, and computer memory), and organizational breakthroughs (such as Henry Ford's inventory-reduction methods and Deming's statistical process control). Yet another example is the case of programmable automation, a technology which was invented in the US, but which has since diffused more widely in Europe and Japan.

This paper provides evidence that adversarial customer-supplier relationships are a key factor in explaining the low rates of adoption of programmable equipment in the US. The paper examines the impact on adoption of computer numerically controlled (CNC) machine tools ${ }^{1}$ of the relationship between components suppliers and their customers in the automotive industry. ${ }^{2}$

The paper is organized as follows. The first section reviews the literature to develop three explanations of the determinants of technology adoption: efficiency, market power, and active customer commitment. The second section builds a model which includes each of the three explanations as special cases. The third section applies the model to $\mathrm{CNC}$, and the fourth describes the data source, a survey of automotive suppliers which I conducted in 1989, and presents results from estimating the model. The

\footnotetext{
'A computer numerically-controlled (CNC) machine tool is controlled by a single dedicated minicomputer or mierocomputer. Computer numerical control allows a machine tool to be programmed, in contrast to conventional machine tools. which are operated by machinists who control the tool through the use of gears and cams. CNC tools can significantly increase productivity, quality, and product variety.

In a comprehensive study of 21 machining-intensive industries in the United States, Kelley and Brooks (1991) found that in 1987. only $11 \%$ of all machine tools in use were programmable and that only $43 \%$ of firms had even one computer-controlled tool. For Japan. they cite studies showing that $30 \%$ of machine tools in use in 198.5 were programmable. (Kelley and Brooks estimate this figure woud have grown to $40 \%$ by 1987.) Edquist and Jacobsson (1988. p.1(14) calculate for 1984 the number of computer-controlled (both $\mathrm{NC}$ and $\mathrm{CNC}$ ) machine tools per employee in engineering industries; they find the density in Japaun and Sweden to be nearly double that of the US. The disparity in production is even greater; by 1985 Japanese ourput of computer-controlled machine tools was 10 times that of the US (Ray. 1989).
}

\footnotetext{
2Machine-tool adoption involves two sets of customer/supplier relationships: hetween the component-maker and the machine-1ool vendor. and hetween the automaker and the eomponent-maker. This paper studies the second type of relationship: see Kelley and Brooks (1991) for a discussion of the relationship hetween mantufacturers and machine-tool vendors.
} 
conclusion argues that because of their effects on incentives to adopt new technology, supplier/customer relationships play a key role in economic development.

\section{Models of technology adoption}

Much of the economics literature on technology adoption follows the approach developed by Mansfield $(1968,1989)$ in arguing that firms adopt new technologies based on their expected profits from doing so. For example, Mansfield (1989) explains the diffusion of industrial robots on the basis of differences in firms' estimates of their own profitability of adoption. (Mansfield does not explore the determinants of estimated profitability.) Below, I look at three major schools of thought about what might determine estimated profitability.

a. Efficiency, In a truly seminal 1957 study of the diffusion of hybrid com in the United States, Griliches, like Mansfield, argues that technology adoption is related to profitability. However, Griliches's measures are more closely related to the efficiency of adoption, which is not always correlated with the profitability of adoption by a user. For example, he uses yield improvements achievable with hybrids in an area as a proxy for hybrid seeds' profitability to farmers. However, yield improvement affects the total producer and consumer surplus available to be divided among farmers, seed companies, and consumers. Each group's share will not automatically increase when total surplus increases. ${ }^{3}$

Many other studies of teclnnology adoption have followed Griliches in assuming that a new teclinology will be adopted if and only if it leads to an increase in total surplus. See for example the studies of adoption of NC machine tools ${ }^{4}$ done by Romeo (1975) and Globerman (1975), and Oster's (1982) study of

\footnotetext{
${ }^{3}$ Use of hybrids changes the relative bargaining power of farmers and seed companies. The reason is that once farmers switch to hybrids. they lose the ability to produce their own seed from the previous year's crop, because the offspring of hybrid seed are much less productive than non-hybridized com. Instead, farmers must buy seed every year from oligopolistic seed compinies (Berlan and Lewontin. 1986). This situation is an example of Williamson's (1985 p.63) "fundamental transformation". in which once agents invest in specific assets, they are subject to being "held up" by their suppliers for the value of the asset-specific rents.

${ }^{4} \mathrm{NC}$ (numerical control) is an earlier version of $\mathrm{CNC}$, in which instructions are conveyed to the tool hy means of a paper tape insteid of a computer.
} 
diffusion of the basic oxygen furnace.

b. Market Power. In contrast to the "efficiency" school discussed above, ability to appropriate profits played a central role in the work of Joseph Schumpeter (1950). In particular, he argued that high market share allowed firms to be more innovative, because of their greater ability to reap private profit from their risk-taking behavior. Evidence that market power affects the technology adoption decision is provided by von Hippel (1988), who finds in many industries that market share is a significant determinant of a firm's decision to adopt a new teclnology. Hannan and McDowell (1984 $\mathrm{a}$ and $\mathrm{b}$ ) find that banks in more concentrated markets in the US are more likely to adopt automatic teller machines, while Espitia, Polo, and Salas (1991) find that speed of ATM adoption is maximized at intermediate levels of concentration for Spanish banks.

c. Customer commitment. In the "market power" tradition, relationships between customer and supplier firms are impersonal and arm's-length. In contrast. Ronald Dore (1983, 1986) has argued that one of the keys to Japanese success has been their use of "relational contracting", where "trading relations [are treated as] particularistic personal relations", in which both parties have an obligation to maintain the stability of the relationship, rather than deal with the firm that offers the best deal at the moment. Dore argues that the greater security and trust involved in such relations leads to more investment and a more rapid flow of information (1983, pp.464,475).

Evidence for this approach is provided by Kelley (1993), who finds that firms whose customers provide them with technical information are more likely to adopt programmable automation, including $\mathrm{CNC}$. Lane (1991) shows that US coal companies which are vertically integrated with their customers are more likely to adopt continuous mining machines. The MIT Commission on Industrial Productivity (Dertouzos. Lester. and Solow. 1989) and Piore and Sabel (1984) have both pointed to adversarial supplicr/customer relationships as a factor which has hindered US competitiveness. Carlsson and Jacobsson (1994) explain the high rate of adoption of flexihle automation by Swedish firms as in part due to close supplier/customer linkages. 
Oliver Williamson $(1975,1985)$ looks at how the nature of contracts between firms affects their investment in specific assets. While Williamson does not explicitly consider the determinants of technology adoption, his theory can be readily applied to the case of investment in a specific asset which embodies new technology. Williamson points out that conditions such as asset specificity, bounded rationality, uncertainty, and opportunism lead to increases in the costs of carrying out transactions using markets. These costs may be high enough to discourage parties whose relationship is governed by a market from making efficient investments.

For example, Monteverde and Teece (1982) show that automakers tend to vertically integrate the production of parts characterized by asset specificity. The authors explain this preference for vertical integration on the basis of the difficulty of designing the complex contingent contracts necessary to carry out an arms'-length market transaction. If there arises a situation unforeseen by the contract, a party which has invested in an asset which is specific to another firm is vulnerable to a "hold-up", in which the other firm reneges on its promise to provide a competitive return, since the investment is now sunk. ${ }^{5}$

Transaction-cost theorists assume that although it is theoretically possible that contracting arrangements will deter investment, institutional arrangements will in practice adjust so that parties have the incentive to invest efficiently. In the case above, Monteverde and Teece assume that firms choose the level of vertical integration so as to produce the socially-efficient amount of asset specificity. ${ }^{6}$ That is, while markets may fail, overall economic organization does not.

\footnotetext{
${ }^{5} \mathrm{~A}$ correlition between asset specificity and vertical integration is also found in econometric work by Joskow (1985), and Liehermin (1991). A correlation between asset specificity and contract length or other safeguards is reported by Joskow (1987). and Heide and John (1988). These authors interpret their findings as support for the transaction-cost prediction that in exogenous level of asset specificity leads to modifications in governance mechanisms.

"In contrast. Crandall ( 1968) argues that US automakers chose inefficiently high levels of asset specificity, so as to reduce the size of the market for a given type of replacement part. By designing a Chevrolet alternator to be incompatible with a Pontiac altemator. for example. General Motors could decrease the likelihond that an independent firm could enter the replacement alternator market at efficient scale.
} 


\section{A Model of Supplier Relations and Investment}

In this section, I develop a model which contains as special cases each of the three hypotheses about technology adoption discussed above.

Consider first a discrete version of the model in Tirole (1988, pp.22-7). A customer and a supplier are considering a joint project which requires the supplier to invest an amount $I$ in period 1 , and which in period 2 has value $v$ to the customer and production cost $\mathrm{c}$ for the supplier. The supplier's investment is specific to the customer and is worthless after period $2 ; 1, v$, and $c$ are common knowledge and are net of opportunity costs. If the parties do not sign an agreement in period I but the supplier invests anyway, then in period 2 the gains from trade are $v-c$, since the supplier's investment is sunk. Suppose the customer and the supplier engage in Nash bargaining in period 2. Then the supplier's profit from the project is

(1) $\pi^{\mathrm{f}}=\alpha(\mathrm{v}-\mathrm{c})-\mathrm{I}$,

where $\alpha$ is the supplier's share of the gain from trade. A profit-maximizing supplier will invest if

(2) $\alpha(v-c)>$ l.

In contrast, it is socially optimal to invest as long as

(3) $v-c>$ I.

Since $\alpha<=1$, the supplier will not invest in some projects which are socially optimal. In contrast, if the supplier and the customer sign a long-term contract in period I (before the supplier invests), the supplier will invest as long as

(4) $\pi^{\mathrm{f}}=\alpha(\mathrm{v}-\mathrm{c}-\mathrm{I})>0$,

which is optimal hecause (4) is satisfied if and only if (3) is satisfied.

In the case of the short-term contract, the supplier underinvests heciause it bears all of the costs of the investment. hut receives only $\alpha$ of the returns. In contrast, under a long-term contract the supplier pays $\alpha$ of the costs and receives $\alpha$ of the returns. In the general case, the supplier receives $\alpha$ of the henelits and pays a different proportion $(\gamma)$ of the costs: 
(5) $\pi^{f}=\alpha(v-c)-\gamma I$.

Why would a customer not offer a contract such that $\alpha=\gamma$ if this arrangement is necessary for efficient investment? One reason is that a customer with oligopoly rents may prefer inefficient short-term supplier relationships to long-term contracts, if a long-term contract makes it possible for the supplier to gain a larger share of the oligopoly rents.

We can extend the model above to show conditions under which bargaining-power considerations preclude efficient contracts. ${ }^{7}$ Suppose the customer reaps oligopoly rents, F, in its final-product market. Suppose also that the customer incurs a cost of switching from one supplier to another. ${ }^{8}$

As long as the switching costs are greater than zero, the customer must give the supplier access to a share of its oligopoly rents if a long-term contract is signed. The reason is that the supplier can now hold up the customer if unforeseen contingencies arise during the contract period. For example, if the customer wants to change the specifications of the supplier's component (a common occurrence in the auto industry), the supplier can refuse to renegotiate the agreement unless it is paid handsomely for its trouble. The customer could compensate for this later loss of bargaining power by requiring the supplier to bid for the right to obtain a long-term contract. However, I show below that in the presence of supplier uncertainty about the size of the oligopoly rents, there may he no mutually-acceptable bid due to adverse selection.

The model has two time periods. In the auction period, the customer accepts bids for the right to a long-term contract. If agreement is reached, the supplier makes the investment and the parties divide the mutual gain (v-c-I) as well as the customer's oligopoly rent, F. In the auction period, we treat the sharing parameters, $\alpha_{1}$ and $\alpha_{s}$, as fixed. In the production period which follows, we determine $\alpha$ endogenously.

Assume the customer first privately observes $F$, and then receives bids from suppliers for a contract

${ }^{7}$ This section draws on Helper and Levine (1992).

8These switching costs are due to such factors as the expenses of moving customer-owned tooling from one supplier to another; establishing communications links; and training suppliers to use the customer's procedures for tasks such as qualifying firms who supply equipment and materials, and documenting quality-assurance efforts. These costs may be quite low. However. as shown helow. switching costs rise if the customer signs a long-term contract with the supplier. 
under which the customer pays $(1-\gamma)$ of the investment cost. ${ }^{9}$ Suppose that conditions are such that suppliers would not invest in the absence of a long-term contract ${ }^{10}$. The customer should accept a bid B if

(6) $\left(1-\alpha_{1}\right)(F+v-c)-(1-\gamma) I+B>\left(1-\alpha_{s}\right) F$,

where $\left(1-\alpha_{1}\right)$ is the customer's share of joint profits if a long-term agreement is reached, and $\left(1-\alpha_{s}\right)$ is its share if agreement is not reached. Assume $\mathrm{F}$ is uniformly distributed between 0 and $\mathrm{F}_{\max .}$. Although the supplier observes $\mathrm{F}$ after the auction period, we assume that $\mathrm{F}$ cannot be verified by the courts. Thus, contracts cannot be contingent on $\mathrm{F} .{ }^{11}$

If many suppliers bid for the contract, then competition will drive their expected profits from the investment to zero:

(7) $\left.E\left\{\alpha_{1}\left(\mathrm{Fl}_{\mathrm{B} \text { accepped }}+\mathrm{v}-\mathrm{c}\right)-\gamma \mathrm{I}\right)-\mathrm{B}\right\}=\mathrm{E}\left\{\alpha_{\mathrm{s}} \mathrm{F}_{\mathrm{B} \text { accepped }}\right\}$.

However, the customer will not accept the supplier's bid unless (6) is satisfied, even if the relationshipspecific rents are positive. The expected value of $\mathrm{F}$ given that the bid is accepted is

(8) $E\left(\left.F\right|_{B \text { acceped }}\right)=E\left(F \mid\left(1-\alpha_{s}\right) F<\left(1-\alpha_{1}\right)(F+v-c)-(1-\gamma I)+B\right.$, or

(9) $\mathrm{E}\left(\mathrm{FI}_{\mathrm{B} \text { accepled }}\right)=\left[\left(1-\alpha_{1}\right)(v-c)-(1-\gamma) \mathrm{I}+\mathrm{B}\right] / 2\left(\alpha_{1}-\alpha_{\mathrm{s}}\right)$.

Substituting (9) into (7) gives

(10) $\mathrm{B}=\left(1+\alpha_{1}\right)(v-c)-(1+\gamma) \mathrm{I}$.

'Note that suppliers' bids could be paid in kind, as in an offer of "free" product design. Note also that if the supplier has sufficient market power ( $\alpha_{s}$ is high enough), the customer will face switching costs high enough to protect the supplier's investment even without a long-term contract.

${ }^{10}$ That is. suppose that $\alpha_{s}(v-c+F)-I<\alpha_{s} F$. It is straightforward to show that if the supplier would invest without a longterm contract, the customer cannot increase its profits by offering a long-term contract.

"Adverse selection precludes many efficient bargains under more general assumptions concerning the distribution of F. A uniform distribution implies that the absolute level of uncertainty about the level of increases as $F_{\max }$ increases. This is intuitively platusible, since the ahsolute level of uncertainty surrounding Chrysler's product market rents is less than that surrounding GM's. As Helper and Levine (1992) show, the adverse-selection result holds if $F$ and (v-c-I) are not additive. In a repeated game, the supplier would over time learn about the customer's product market rents. alleviating the adverse-selection problem. On the other hand this knowledge is valuable and the rents are uncertain, making the value of the initial contract even more uncertain. This effect increases the severity of the initial adverse-selection problem. Therefore. placing the model in a repeated-game context would not change the basic result that adverse selection precludes some efficient transactions. 
The probability that the customer will accept this bid is

$$
\begin{aligned}
& \text { (11) } P=\operatorname{Pr}\left[B+\left(1-\alpha_{1}\right)(F+v-c)-\gamma I>\left(1-\alpha_{s}\right) F\right] \text {, or } \\
& \text { (12) } P=2(v-c-I) /\left(\alpha_{1}-\alpha_{s}\right) F_{\max } .
\end{aligned}
$$

If the relationship-specific rents are positive but small relative to the maximum final-product market rent $F_{\max }$ or the increase in the supplier's bargaining share $\left(\alpha_{1}-\alpha_{s}\right)$, there is no bid which is acceptable to both the supplier and the buyer, and investment will be inefficiently low. ${ }^{12}$

The auction stage took the bargaining power parameters $\alpha_{s}$ and $\alpha_{1}$ as given. Following Shaked and Sutton (1984), we derive $\alpha_{s}$ and $\alpha_{1}$ as the outcome of a noncooperative game that is played over real time during the production stage after the auction. The supplier observes $\mathrm{F}$ in the production period, so information is complete and symmetric. When the production period begins, the two players alternate in proposing how to divide the total rents from the relationship. The other player may respond by either accepting the offer or making a counteroffer in the next period. In order to eliminate first-mover advantages, we examine equilibrium as the time between successive offers approaches zero. Bargaining is costly, in the sense that the present value of the surplus to be divided falls by the factor $(1-\delta)$ in each period that agreement is not reached. Let $\delta \in(0.1)$ be the sum of the (common) continuous time discount rate, and the instantaneous rate of decline of the surplus which occurs if the players are devoting energy to bargaining and therefore are not paying full attention to producing. Assume that the customer is locked into bargaining with the supplier it chose in the auction stage for cither l periods (in the case of a long-term contract) or s periods (if no long-term contract is signed). After the lock-in period is over, the customer obtains the input at cost $\mathrm{C}$ (either hy making the part in-house, huying it on an arm's-length market, or buying it from another long-term supplier who must rapidly start up production).

Using hackward induction. Shaked and Sutton (1984) show that this game has a unique perfect

\footnotetext{
${ }^{12}$ The result that a customer who receives oligopoly rents will reject some efficient contracts is robust to at variety of specitications about the nature of the suppliers. For example. the arm's-length market for inputs may be perfectly competitive (implying $\alpha_{s}=0$ ), or suppliers may bargain one at a time .
} 
equilibrium, in which

$$
\begin{aligned}
& \text { (13) } \pi^{f}=\alpha_{t}(F+v-c-I) \\
& \text { (14) } \pi^{p}=\left(1-\alpha_{t}\right)(F+v-c-I), \text { where } \\
& \text { (15) } \alpha_{t}=C+(1-\delta)\left(1-\delta^{2 t}\right) \delta /\left(1-\delta^{2}\right) .
\end{aligned}
$$

Thus, (13) and (14) describe the division of surplus assumed in the auction stage above, where $\pi^{\mathrm{p}}$ is the purchaser profit, and $\mathrm{t}=(\mathrm{l}, \mathrm{s})$. By inspection, we can see that $\mathrm{I}>\mathrm{s}$ implies $\alpha_{1}>\alpha_{\mathrm{s}}$. Thus, the longer the customer is locked into bargaining with a particular supplier (e.g., the longer the customer's contract with the supplier), the greater the supplier's share of the surplus.

\section{Investment in CNC and Customer/Supplier Relations}

Compared to conventional general-purpose machines, CNC offers greater labor productivity (since time spent repositioning the work piece for different passes is greatly reduced), greater conformance quality, and the ability to machine more complicated parts than a skilled machinist could. Compared with dedicated equipment, $\mathrm{CNC}$ offers faster set-ups, since only the program has to be changed--hardware is not affected. (Romeo, 1975; Noori, 1990, pp.24-5; Kelley and Brooks, 1991.)

CNC machines have been commercially available since the mid-1970s. However, a comprehensive 1987 survey (Kelley and Brooks, 1991) of US metal-working establishments found that only $43 \%$ of plants had even one computer-controlled machine tool, and that less than $11 \%$ of the stock of machine tools in use was computer-controlled.

Why have adoption levels been so low? Below, 1 show that CNC investment in the auto industry fits the model of section 2 in that the investment is specific, and auto suppliers have the ability to hold up their customers.

Even though $\mathrm{CNC}$ equipment itself is general-purpose, if a firm or division has few markets, any addition to its fixed capital increases the firm's vulnerability to a "lold-up". To see this, suppose the firm can neither instantanecously generate new customers nor instantaneously sell and buy hack its equipment to suit its 
level of demand. Under these conditions, if one of the firm's major customers stops (or threatens to stop) buying from it, the firm's losses will increase with the level of its fixed costs. ${ }^{13}$

For example, according to Jack Reilly, CEO of Tenneco Automotive (a subsidiary of a large, multinational firm), a five-year contract with Ford was crucial to Tenneco's decision to equip its exhaustsystem production facilities with $\mathrm{CNC}$ machines. The reason was that Tenneco was unwilling to incur the risk of having such high fixed costs without some level of guaranteed demand, since the firm could not instantaneously redeploy all its equipment were it to lose Ford as a customer. ${ }^{14}$ In contrast is a small Indiana stamping supplier I visited in 1989. According to the sales manager, the firm's role was "to keep the other suppliers honest"; its contracts were at most one year long. Although the plant had a small tool room, the investment required to buy a CNC machine was out of the question; it took two years of scrounging for the firm to come up with the few thousand dollars necessary to furnish a lunch room for the workers, so they no longer had to eat at their machines (interview, July 1989).

An investment in $\mathrm{CNC}$ is large, so the increased vulnerability to hold-up is significant. First, the machines themselves are expensive. Noori $(1990$, p.25) estimates that conventional machine tools cost $\$ 10,000$ to $\$ 30,000$, while NC costs $\$ 80,000$ to $\$ 150,000$ and CNC costs $\$ 250,000$ to $\$ 1,000,000$. Using conventional accounting methods, which do not take into account the complementarities described below, the payhack period is likely to be at least ten years (Noori, 1990).

Second. the firm must make other investments to make the equipment investment pay off. CNC requires employees to have different skills--programming instead of manual dexterity. Therefore, CNC programmers must either be hired (which means the firm must search for personnel in a different labor market from that which it is used to), or trained (which means the firm incurs training expenses, and loses the

\footnotetext{
${ }^{13}$ The president of a small auto-parts firm made an analogy to the situation of an economist who goes into debt to take a mathematics course. Although math skills are general, they don't allow the economist to teach in another field such ats accounting. and the extra debt makes her more vilnerable to bankruptcy should the market for economists shrink (interview. July 1995).
}

${ }^{14}$ In return for the contract. Tenneco agreed to $5 \%$ annual price reductions. (interviews. October 1988 and 0 ctober 1989 ). 
services of its skilled machinists during the training period).

Moreover, profitable use of $\mathrm{CNC}$ and other types of flexible automation requires a different operations strategy, one which aims to create a "just-in-time" production environment of small batch sizes and pressure for continuous improvement. Concomitantly, firms must change their marketing strategy; salespeople must learn a great deal about customers' needs, so that they can sell CNC's capabilities for product modification and customization. ${ }^{15}$ That is, investments in $\mathrm{CNC}$ are complementary with investments in many other areas of the firm, in the sense of Milgrom and Roberts (1992, p.543). The result is that even if the services of CNC-trained machinists could be bought and sold on an arm's-length market. the firm would still need to make nonredeployable investments in coordinating their capabilities with other parts of the organization, such as the marketing and production control departments.

These expenditures make the firm's fixed costs much higher than they were with conventional machine tools. These fixed costs mean that even though $\mathrm{CNC}$ increases a firm's flexibility by increasing the range of products it can offer, it also increases a firm's exposure to risk.

How can relationships with customers improve the prospects for CNC adoption? The supplier needs some assurance that customers will continue to purchase its products at a remunerative price for some length of time, so that it can reap at least a market rate of return on its investment. Customers can provide this commitment in several ways, including financial ties such as equity investment or long-term loans; long-term contracts; or by demonstration of a concern for its reputation for fair dealing. Commitment can also be provided involuntarily, as when a customer faces an oligopolistic supply industry. ${ }^{16}$

\footnotetext{
ishe preceding paragraphs are based on discussion with managers and workers at metalworking firms, and with Haunah Roditi, formerly of the Machine Action Project. a technical assistance agency in Springfield. MA. See also Kelley and Brooks (1991).

"The argument is similar to Williamson's discussion of "dedicated assets". which are "discrete additions to generalized capacity which would not be put in place but for the prospect of selling a large amount of product to a particular customer. Premature termination of the contract by the buyer would leave the supplier with a large overhang of capacity that could be disposed of only at distress prices." (198.5, p.194)
} 


\section{Methods}

We can use the model in section 2 to derive an estimating equation. Suppose that $(v-c)$, the change in production cost associated with investing in $\mathrm{CNC}$, is measured with error $\mathrm{u}_{\mathrm{i}}$, which is $\mathrm{IN}\left(0, \hat{\sigma}^{2}\right)$, and is uncorrelated with the disturbance of $F$, the customer's final-product market rent. Then the probability that the supplier will invest is

(16) $\operatorname{Pr}(\mathrm{CNC}=1)=\int_{\gamma=0}^{1} \operatorname{Pr}\left(\alpha_{1}(\dot{v}-\mathrm{c}+\mathrm{u})>\gamma \mathrm{D}\right) * \mathrm{Pd} \gamma$, where

(17) $\mathrm{P}=2(v-c-I) /\left(\alpha_{1}-\alpha_{s}\right) F_{\text {max }}$.

That is, for any proportion $\gamma$ of the investment cost to be paid by the customer, the supplier's willingness to invest depends on the probability that the investment will be profitable times the probability (P) that it will obtain a contract that pays $\gamma$ of the cost. Summing over the possible values of $\gamma$ gives the overall probability that supplier will invest. We interpret $\gamma=1$ as the case where no agreement is reached on a contract which would require the customer to pay for any part of the investment. In this case therefore, $\alpha_{1}=\alpha_{\mathrm{s}}$.

Equation (16) contains as special cases each of the technology-adoption models discussed in section I. This formulation suggests the following hypotheses:

\section{A. The supplier is more likely to invest in CNC if the efficiency of CNC investment ( $v-c-I)$ is}

high. As discussed in section 1, efficiency-based models of technology adoption assume that difficulties in distributing gains from trade do not impede adoption. This is equivalent to assuming $\alpha_{1}=\gamma$ in (16).

CNC's operating-cost advantage (v-c) depends on:

Wages of production workers (HIWAGE). Since CNC machines are faster than general-purpose equipment, the return on investment increases with the cost of labor.

Technical complexity of supplicr's product (COMPLEX). Since CNC tools can machine some parts in ways which conventional machine tools cannot (for exanple, CNC can perform operations on multiple axes), this variable should enter positively.

Production lot size (BATCH). $\mathrm{CNC}$ is most effective at runs which are long enough to justify the fixed cost 
of writing a program (usually just a few parts), but not so long as to justify the installation of dedicated equipment. Since the firms in my sample supply production parts (not prototypes) to the auto industry, their volumes are large enough to meet the lower threshold. Thus, BATCH should enter negatively. (That is, the distribution of BATCH in my sample is truncated at the lower end.)

Eirmsales (SALES). This variable proxies for firm-level economies of scale in management, since in the absence of strong extra-firm institutions such as close relationships with customers or government agencies, a firm must rely on internal resources to make the organizational changes necessary to profitably adopt $\mathrm{CNC} .^{17}$ The variable also proxies for economies of scale in marketing: equipment vendors have to pay fewer visits per machine sold. ${ }^{18}$

CNC's investment cost (I) depends on:

Age of firm (NEW). New firms (those that entered the original-equipment auto market after 1983) are likely to have bought equipment recently. Because new equipment is more likely to embody new technology (David. 1969) new firms face a lower cost of investing in CNC.

Skill at introducing entirely new processes (HISKILL). Firms which rate themselves high on this dimension should have a lower cost of implementing $\mathrm{CNC}$, so they should be more likely to adopt.

\section{B. The supplier will be more likely to invest in $\mathrm{CNC}$ if it has high bargaining power $\left(\alpha_{s}\right)$.}

\footnotetext{
${ }^{17}$ If one expects CNC use to he distributed uniformly across the population of machine tools, then firms with more machine tools should be more likely to have one of them be computer-controlled. To the extent that a firm's sales are correlated with its number of machine tools. the sales variable is picking up only this scale factor. and does not contain information about economies of scale. However, the sales data is not perfectly correlated with number of machine tools. since large firms do not always have lots of machine tools--their primary production activity may be something other than metalcutting, such as forging or assembly. (Even if they are engaged in metal-cutting. long production runs may make fixed automation a cost-effective alternative to both CNC and conventional machine tools (Carlsson and Taymaz, 1994).) In addition, the high fixed costs of CNC adoption casts doubt upon the hypothesis of uniform adoption across all sizes of firms.
}

\footnotetext{
${ }^{18}$ Griliches (1957) gives a similar rationale for his hypothesis that areas with larger farms were faster to adopt hybrid corn. However. this variable could also be included in the supplier relations category, because there exist institutional structures under which this variable would not be significant: cooperatives of small firms, where vendors could make one sales pitch to a group of companies, or government technical assistance programs targeted at small firms.
} 
Authors such as Schumpeter (1950) argue that a firm's innovative behavior is affected by the share of the gains from trade the supplier can appropriate, as well as by efficiency concerns. However, these authors focus on market power as the key determinant of appropriability. They do not allow for the possibility that deals between individual suppliers and customers could resolve these problems. Implicitly they assume $\gamma=0$ in (16). Here, $\alpha_{\mathrm{s}}$ depends on:

Supplier's market share (SHARE). When a firm has a higher market share, its customer will have fewer alternative sources of supply, so the firm can bargain for a bigger share of the benefits from CNC adoption. Supplier's percent of sales to auto industry (AUTO) measures the extent of a firm's dependence on just three customers--the US-owned automakers ${ }^{19}$. A high value of AUTO means a firm has few alternative sources of demand, so that the firm is less likely to be able to replace lost orders quickly. Therefore, this variable should have a negative impact on the probability of $\mathrm{CNC}$ adoption.

\section{A supplier will be more likely to invest in $\mathrm{CNC}$ if it has a high probability of active}

commitment (P) from an individual customer ${ }^{20}$ This commitment is measured by:

contract length (CONTRACT). A longer contract gives the firm a longer planning horizon, important because of CNC's long payback period and ties to other assets that are specific to just a few customers. Other things equal, a longer contract increases the probability that the customer will pay a proportion greater than zero of the investment cost.

Equations (16) and (17) provide three ways to test the "active commitment" hypothesis. First, I

\footnotetext{
"Few US-owned firms had significint business with Japanese-owned automakers in 1989. Japanese transplant suppliers (less than $12 \%$ of the sample) did not sell to a significantly higher number of automakers than their US-owned counterparts.

${ }^{20}$ Institutional factors other than customer/supplier relationships are often important in determining adoption rates. For example. Carlsson and Jacobsson (1994) argue that adoption rates are determined by the entire "technological system". including state-sponsored "bridging institutions", and a critical mass of using and supplying firms (See also Carlsson. 1995). Kelley and Brooks ( 1991 ) show that the internal organization of the firm, including the labor-management relationship. is also important. In this paper I will focus on customer/supplier relationships. I take into account internal organization indirectly, in the sense that the need to change it (as described in section 2) adds to the cost of CNC adoption and therefore to the advintages of customer commitment. In the US auto industry, bridging institutions which would provide assistance in adopting $\mathrm{CNC}$ have been largely absent.
} 
estimate a probit equation using contract length as a proxy for P. Second, I estimate (17) and (18) as a recursive system. Finally, I estimate (17) explicitly, using grid search to maximize the likelihood. Integrating (17), the probability that $\mathrm{CNC}=1$ is

(19) $P[1+(\alpha / I) \ln ((1+\exp (-v+c)) /(1+\exp ((I / \alpha)-v+c))]$

D. A customer will be more likely to accept a supplier's bid for a long-term contract ( $P$ will be higher) if its final product market rents are low. In equation (18), a higher value of $F_{\max }$ reduces the value of $P$, because the customer wants to protect its final-product market rents from the possibility of hold-up by suppliers. However, applying Schumpeterian reasoning to automakers as well as their suppliers, one sees that if profits are too low, the automaker's ability to credibly commit to paying a high proportion of the cost of investing in the future will be reduced. Thus, we predict :

Customer's maximum returm on assets. 1970-1989 (CROA) should enter the contract equation positively, while the square of this variable (CROASQ) should enter negatively.

\section{Data}

A 1989 survey of automotive suppliers that I conducted provides an opportunity to test the hypotheses stated above. The survey was conducted under the sponsorship of the International Motor Vehicle Program at MIT. The survey questionnaire was based on in-depth interviews with almost one hundred managers and workers at auto assemblers and their suppliers.

In spring 1989, a survey was mailed to every automotive supplier and automaker component division named on the following lists: (1) the 1989 Elm Guide to Automotive Sourcing in the United States, and (2) members of the Motor and Equipment Manufacturers' Association who sell components directly to the automakers. Thus, the survey was mailed to virtually every first-tier supplier to manufacturers of cars and light trucks in the United States. The target respondent was the divisional director of inarketing at independent firms, and the divisional business manager or director of strategic planning at automaker components divisions. I selected these individuals based on information gathered from field interviews that 
they would have the broadest knowledge about both customer relationships and about their firms' products and processes. These individuals had a great deal of experience in the industry; they had been with their firm for a median of 9 years, and in the auto industry for 11 .

Because many companies supply their customers with several different types of products, and their relationships with their customers differ by product, respondents were asked to answer the survey for one customer using one product which was typical of their company's output. In order to preserve confidentiality and to minimize the time required to fill out the survey, respondents were not asked to provide exact data on their firm's sales, etc, but rather to check boxes indicating ranges.

The response was double the norm for business surveys; 499 filled-out questionnaires were received, for a response rate of $47 \%$. Furthermore, responses from the four major groups who received the survey-automaker components divisions, Japanese-owned firms, MEMA members (who tend to be small and medium-sized independent firms), and large independent firms--were close to their proportions in the population.

The dependent variable "CNC adoption" was one if the business unit had at least one CNC machine making the product for which the survey was filled out, and zero otherwise. Business units for which the respondent said that the technology was not applicable or that they didn't know were excluded from the sample. ${ }^{21}$ Table I describes the variables; table 2 provides summary statistics. ${ }^{22}$

The profit data for the three US automakers comes from COMPUSTAT; return on assets was calculated as operating income/fixed assets for each of the years 1970-89. I obtained similar data for

\footnotetext{
${ }^{21}$ In the results reported below, 213 respondents were excluded because they did not know about the technology, thought it was inapplicable to their business, or (in a few cases) had missing data. I also analyzed a data set in which an auto technology expert judged that for thirty of these firms, CNC is indeed applicable to the manufacture of the product these respondents indicated wats typical of their business. The results for all models were not significantly different for this data set than for that reported. except that the overall fit was not quite as good. Thanks to Daniel Luria. Senior Research Scientist at the Industrial Technology Institute in AnnArbor MI, for evaluating CNC applicability.

${ }^{22}$ In several cases I transformed variables which originally had multiple levels into dummies. The rationale is that respondents are more likely to be able to sort themselves accurately into two groups (high and low skill at adopting new
} 
Japanese automakers, thanks to Marvin Lieberman of UCLA.

\section{Results}

Table 3 shows support for all three hypotheses in section 4: firms are more likely to adopt CNC the higher the efficiency of $\mathrm{CNC}$ for their product, the greater their market power, and the more customer commitment they receive. Maximizing the likelihood function implied by (19) yielded similar results, as shown in Table 5. However, this technique did not produce a significant improvement in the log likelihood, and the results are difficult to interpret, so the rest of the discussion will focus on the probit results.

Column 3 of table 3 shows that efficiency, market power, and active commitment are all important determinants of CNC adoption. In particular, the active commitment variable CONTRACT is significant at better than the $1 \%$ level. As the first two columns of the table show, the impact of the efficiency and market power variables does not change if these are considered separately from the active commitment variables.

The McKelvey-Zavoina pseudo-R2 for the "active commitment" model is .59.

One explanation for these results is that commitment does not cause $\mathrm{CNC}$ adoption; instead, both CNC adoption and commitment are driven by a common third factor, such as being a "good" supplier. In table 3 we have controlled for this possibility by including the variable "HISKILL", which measures the supplier's skill at introducing entirely new processes.

However, it may be objected that this skill is so imperfectly measured that the commitment variables are picking up some of the variance that would be attributed to a properly measured skill variable. A closer look at Table 3 provides one answer to this objection; the coefficient on HISKILL actually rises when commitment variables are included. If the commitment variables were merely proxies for unmeasured skill, then their omission slould cause the coefficient on HISKILL to jump.

Tahle 4 provides more evidence that the commitment variables do have an impact on investment independent of their connection with efficiency. The first column presents estimates of CONTRACT using a linearized version of equation (18), where $\alpha_{1}$, the supplier's bargaining share with a long-term contract, is 
treated as a constant. Both CROA and CROASQ are significant in this equation. This result is consistent with the hypothesis that customers are motivated not only by efficiency criteria in offering contracts to their suppliers, but also by concerns to protect their final-product market rents. These results are robust to a variety of specifications: using the average return on assets (rather than the maximum); omitting outliers (Toyota had an average retum on assets of $40 \%$ and a maximum return of $65 \%$ ); using customer dummies rather than customer ROA; and including dummies for Japanese-owned and automaker-owned supplier plants.

I then calculate CONTRACT (EST) by subtracting out that part of the variance of CONTRACT due to the efficiency variables. Even after adjusting the standard errors, CONTRACT (EST) remains highly significant, again indicating that contract length is not just a proxy for unobserved variables measuring the efficiency of CNC adoption.

These results are also robust. In particular, controls for vertical integration are not statistically significant. .In transaction-cost models, integration is an organizational form which prevents "hold-ups" which can occur where specific assets and uncertainty/complexity are present. In the current framework, integration might be interpreted as a measure of customer commitment, since in practice, wholly-owned divisions are hard for corporations to divest (Helper, 199lb). However, VI is not significant, with or without variables which might be correlated with vertical integration (NEW, AUTO, and COMPLEX) ${ }^{23}$

For those uneasy with subjective evaluations, it is perhaps comforting to note that only two of the variables (COMPLEX and HISKILL) are subjectively measured. Leaving them out has no impact on the result that market power and active customer commitment are correlated with $\mathrm{CNC}$ adoption.

\section{Conclusion}

These results allow us to reject the null hypothesis that relationships between suppliers and their customers do not have an important impact on suppliers' decision to invest in flexible automation. The

\footnotetext{
${ }^{23} \mathrm{No}$ new vertically-integrated divisions were created in the 1980 s, so NEW is zero whenever VI is one. ()ne might think. on transiction-cost grounds, that high levels of AUTO) and COMPLEX would he correlated with high levels of asset specificity, and therefore with vertical integration.
} 
"market power" and "active commitment" variables turn out to be an important addition to the "efficiency" variables commonly specified in technology adoption models. In fact, firms for whom CNC was technically efficient would be unlikely to adopt the technology in the absence of customer commitment. That is, those firms which were new auto suppliers, paid high wages, had high skill at process innovation, a complex product, and a small batch size but had no customer commitment had only a $48 \%$ chance of adopting the technology. If these firms were to be given a one-year contract by their customer, the probability of adoption would rise to $62 \%$. If all variables are evaluated at their means, a six-month increase in contract length produces a 17 percentage-point increase in $\mathrm{CNC}$ adoption. Similarly, a ten percentage-point increase in market share produces an 11-percentage point increase in the rate of CNC adoption.

These results have implications for both theory and policy. On the theoretical front, the paper shows that it is important to integrate questions of appropriability into the technical change literature, in particular by adding supplier relations as a determinant of technology adoption. Second. the paper extends transactioncost analysis, by relaxing the assumption that agents' private maximizing behavior will always produce organizational forms that maximize social efficiency as well.

This paper has found two types of customer/supplier relationships that enhance the adoption of capital-intensive innovations. First, market power helps to ensure appropriability, even on atomistic markets. by reducing customers' ability to exit from a supplier ${ }^{24}$. Second, active commitment by individual customers, either in the form of trustworthy behavior or long-term contracts, allows suppliers to plan on having the high capacity utilization needed to cover CNC's higher fixed costs. Even though $\mathrm{CNC}$ is a general-purpose tecluology in the abstract, it becomes a specific asset when adopted by a firm whose sales are limited to a few customers, since it adds to the firm's sunk costs. Therefore, explicit commitments from customers can

\footnotetext{
${ }^{24}$ In Williamsonian langulage (198.5 p.195), an automaker who specifies the use of a part which can he made only hy a few suppliers has creatted a hostage, a "separate but concurrent investment in specific assets" which halances the suppliers investment in the dedicated asset of CNC. For additional empirical evidence on this issue of "dependence halancing". see Heide and John, 1988.
} 
increase the expected return on such an investment by reducing the risk of a hold-up.

These results have policy implications as well. The implication of an inefficiently low CNC adoption rate is that US auto suppliers will have longer production runs (less ability to produce a variety of products at a point in time, and less ability to quickly and continuously improve products) and lower quality than they would otherwise. This inflexibility will negatively affect US suppliers to the auto industry. In addition, lower equipment investment will reduce economic growth: Dulong and Summers (1991) find that an extra $1 \%$ of GNP invested in equipment is associated with increased G.P. growth of .3 percentage points. They estimate that the social rate of retum on equipment investment in well-functioning market economies is on the order of $30 \%$ per year.

One implication of the foregoing analysis is that a customer firm's purchasing policies have longterm effects. By influencing the incentives of the supplier base to invest in new technologies, these policies affect customers' ability to carry out their strategies--and thereby, national competitiveness.

The results also suggest that technical progressivity is not a matter of having large firms or small firms, as the debate has typically been framed. The key is to have connected firms, firms that work with and make clear commitments to their suppliers and customers. ${ }^{25}$ Therefore, efforts to encourage firms to adopt capital-intensive technology should not focus solely on individual firms in isolation; they should involve a firm's customers as well. That is, it is important to understand backward and forward linkages (Hirschman, 1950) not just among industries, but between particular firms.

\footnotetext{
${ }^{2}$ For example, a $\$ 25$ million firm with a four-year contract has almost as high a prohability of adopting CNC as a $\$ 2.50$ million firm with at one-year contract.
} 


\section{BIBLIOGRAPHY}

Ben-Akiva, M. and Lerman, S. (1985). Discrete Choice Analysis. Cambridge, MIT Press.

Berlan, Jean-Pierre and Lewontin, R. (1986) "The Political Economy of Hybrid Corn" Monthly Review, 3547 (July-August)

Carlsson, Bo, ed. (1995) Technological Systems and Economic Performance: The Case of Factory

Automation. Dordrecht, Kluwer Academic Publishers.

Carlsson, Bo and S. Jacobsson (1994) "Technological Systems and Economic Policy: The Diffusion of Factory Automation in Sweden" Research Policy

Carlsson, Bo and Erol Taymaz (1994) "Flexible Technology and Industrial Structure in the U.S." Small Business Economics. 6 (3), 193-209.

Cainarca, G., M.Colombo, and S. Mariotti (1990) "Firm Size and the Adoption of Flexible Automation" Small Business Economics 2, 129-40.

Crandall, R. (1968) "Vertical Integration and the Market for Repair Parts in the United States Automobile Industry" Joumal of Industrial Economics, 38 (July), 212-34.

David, P. (1969) A Contribution to the Theory of Diffusion, Stanford Center for Research in Economic Growth, Memorandum no. 71.

De Long, J. and Summers, L. (1991) "Equipment Investment and Economic Growth", The Quarterly Joumal of Economics, May, 445-502.

Dertouzos, M., et al. (1989) Made in America: Regaining the Productive Edge. Cambridge: The MIT Press.

Dore, Ronald (1983) "Goodwill and the Spirit of Market Capitalism", British Journal of Sociology 34, 459 82.

Dore, Ronald (1986) Elexible Rigidities Stanford: Stanford University Press.

Edquist, C. and Staffan Jacobsson (1988) Flexible Automation: The Global Diffusion of New Technology in the Engineering Industry Oxford: Basil Blackwell.

Espitia Escuer, Miguel. Yolanda Polo Redondo, and Vicente Salas Fumas (1991) Econ. Innov. New Techn. 1, 295-307.

Globerman, Steven (1975)"Teclnnological Diffusion in the Canadian Tool and Die Industry" Review of Economics and Statistics, 57, 428-34 (November).

Greene, W. (199()) Econometric Analysis. New York:Macmillan.

Griliches. Z. (1957) "Hyhrid Corn: An Exploration in the Economics of Technological Change"Econometrica, 25, 501-22 (October). 
Hannan, Timothy and John McDowell (1984a) "The determinants of technology adoption: the case of the banking firm" Rand Joumal of Economics, 15 (Autumn), 328-35.

Hannan, Timothy and John McDowell (1984b) "Market Concentration and the Diffusion of New Technology in the Banking Industry", The Review of Economics and Statistics. 66.

Heide, Jan and George John (1988). "The Role of Dependence Balancing in Safeguarding TransactionSpecific Assets in Conventional Channels" Joumal of Marketing,54, pp.20-35.

Helper, S. (1991a) "How Much Has Really Changed Between US Automakers and Their Suppliers?" Sloan Management Review, Summer.

Helper, S. (1991b) "Strategy and Irreversibility in Supplier Relations: The Case of the US Automobile Industry," Business History Review 65 (Winter), 781-824.

Helper, S. and Levine, D.I.(1992) "Long-term Supplier Relationships and Product Market Structure", Joumal of Law. Economics. and Organization 8, 561-81.

Hirschman. A. (1950) The Strategy of Economic Development. New Haven: Yale University Press.

Hirschman, A. (1970) Exit. Voice, and Loyalty. Cambridge: Harvard University Press.

Joskow, Paul (1985) "Vertical Integration and Long-term Contracts: The Case of Coal-Burning Electric Generating Plants, " , Jounal of Law, Economics, and Organization, 1, 33-80.

Joskow, Paul (1987) "Contract Duration and Transactions Specific Investment: Emprical Evidence from Coal Markets" American Economic Review, 77, 168-185.

Kelley, Maryellen (1993) "Organizational resources and the industrial environment: the importance of firm size and inter-firm linkages to the adoption of advanced manufactruing technology" Intemational Joumal of Technology Management, 36-68.

Kelley, Maryellen and Harvey Brooks (1991), "External Learning Opportunities and the Diffusion of Process Innovations to Small Firms: The Case of Programmable Automation," Technological Forecasting and Social Change 39: 1, March 1991.

and B. Harrison, "The Subcontracting Behavior of Single vs. Multiplant Enterprises in U.S.

Manufacturing--Implications for Economic Development," World Development 18:9, 1990, pp. 1273-1294.

Klein, B.. Crawford, R.. and Alchian, A.(1978) "Vertical Integration, Appropriable Quasi-Rents. and the Competitive Contracting Process. L. Law and Econ., 21, 297-326.

Lane, S. (1991) "The Determinants of Investment in New Technology", AEA Papers and Proceedings, 81 (May), 262-265.

Lazonick. W. (1990) Business Organization and The Myth of the Market Economy. Cambridge: Cambridge University Press. 
Lieberman, Marvin (1991) "Determinants of Vertical Integration: An Empirical Test” Joumal of Industrial Economics, 39, 451-466.

Mansfield, E. (1968) Industrial Research and Technological Innovation New York: Norton.

Mansfield, E. (1989) "The Diffusion of Industrial Robots in Japan and the United States", Research Policy, $18,183-192$.

Milgrom, Paul and John Roberts (1992) Economics, Organization. and Management. Englewood Cliffs, NJ: Prentice Hall.

Monteverde, Kirk, and David Teece,(1982) "Supplier Switching Costs and Vertical Integration in the Auto Industry," Bell Journal of Economics.

Noori, H. (1990) Managing the Dynamics of New Technology: Issues in Manufacturing Management. Englewood Cliffs, New Jersey.

Oster, Sharon (1982) "The Diffusion of Innovation Among Steel Firms: the Basic Oxygen Furnace" Bell Loumal of Economics, 13, 45-56.

Piore, M, and Sabel, C. (1984) The Second Industrial Divide. New York: Basic Books.

Porter, M. (1983) Cases in Competitive Strategy. New York: The Free Press.

Ray, George. (1989) "Full Circle: The Diffusion of Technology" Research Policy 18, 1-18.

Riordan, M. and Williamson, O. (1985) "Asset Specificity and Economic Organization," International Joumal of Industrial Organization.

Romeo, A.(1975) "Interindustry and Interfirm Differences in the Rate of Diffusion of an Innovation." Review of Economics and Statistics 57, 311-19.

Scherer. F. (1980) Industrial Market Structure and Economic Performance. Chicago: Rand McNally.

Schumpeter, J. (1950) Capitalism. Socialism.and Democracy New York: Harper and Row.

Shaked, Avner and John Sutton (1984) "Involuntary Unemployment as a Perfect Equilibrium in a Bargaining Model" Econometrica, 52, 6, 1351-64.

Stoneman, P. (1983) The Economic Analysis of Technological Change Oxford: Oxford University Press.

Tirole, J. (1988) The Theory of Industrial Organization. Cambridge: MIT Press.

von Hippel. Eric (1988) The Economics of Innovation. Oxford University Press.

Williamson, O.(1975)_Markets and Hierarchies. New York:Free Press.

Williamson, O.(1985) The Economic Institutions of Capitalism. New York: Free Press. 
Table 1. Variable Descriptions

NAME

$\mathrm{CNC}$

\section{Efficiency Variables \\ NEW}

BATCH

COMPLEX

SALES

HIWAGE
HISKILL

\section{DEFINITION}

$=1$ if business unit used computer numerical control in 1989

$=0$ if $\mathrm{CNC}$ is applicable to producing business unit's typical product, but was not adopted in 1989

$=$ missing otherwise

$=1$ if the business unit did not directly supply any automaker in 1984

$=0$ otherwise

$=1$ if business unit rates itself as above average in its industry in introducing new processes

$=0$ otherwise

production lot size for the business unit's typical product:

$$
\begin{aligned}
& =1 \text { if lots last the customer }<1 \text { day } \\
& =2 \text { if lots last } 1-7 \text { days } \\
& =3 \text { if lots last } 8-30 \text { days } \\
& =4 \text { if lots last more than } 30 \text { days }
\end{aligned}
$$

$=1$ if business unit's typical product is highly complex ( $=5$ on original 5-point scale)

$=0$ otherwise

$=1$ if firm's annual sales are less than $\$ 4$ million

$=2$ if sales are $\$ 4-25$ million

$=3$ if sales are $\$ 26-100$ million

$=4$ if sales are $\$ 101-500$ million

$=5$ if sales are $\$ 500$ million to $\$ 1$ billion

$=6$ if sales are greater than $\$ 1$ billion

$=1$ if wages and henefits for production workers who make the typical product are greater than or equal to average for respondent's industry

$=0$ otherwise

Market Power Variables AUTO

= percent of firm's sales that end up as original equipment for automobiles or light trucks

SHARE

= business unit's U.S. market share for product line

Supplier Relations Variable

CONTRACT = length of contract (in years) with automaker for the product/6

CustomerProfit Variables

$\mathrm{CROA}=1+$ Customer's maximum return on assets, 1970-89

CROASQ $\quad=(\mathrm{CROA})$ squared 
Table 2. Descriptive Statistics

\begin{tabular}{lcr} 
Variable & \multicolumn{1}{c}{ Mean } & Std.Dev \\
CNC & & \\
CONTRACT & 0.75738 & 0.42937 \\
NEW & 0.66393 & 0.19843 \\
HISKILL & 0.35738 & 0.48001 \\
COMPLEX & 0.50492 & 0.5008 \\
BATCH & 0.1541 & 0.36164 \\
SALES & 2.3902 & 0.74022 \\
SHARE & 3.5738 & 1.4288 \\
AUTO & 0.64543 & 0.24141 \\
CROA & 0.9071 & 0.27125 \\
CROASQ & 1.4053 & 0.097177 \\
& 1.9754 & 0.26316
\end{tabular}

$N=305$ 
Table 3. Probit Results--Dependent Variable CNC$$
1
$$

Efficiency

Model

Yariable

Coefticien!

-0.93034 ..

0.36571 ..

0.32953

$2893 E-02$

$0.78652 \cdots$

$0.26591 \cdots$

0.36919

SALES

HIWAGE

AUTO

SHARE
CONTRACT

$\log 1$

$-147.768$

0.06748
0.2306
Markel Power

Model

\begin{tabular}{c} 
coefficient \\
\hline \\
-0.00459 \\
$0.47091 \cdots$ \\
$0.4966 \ldots$ \\
-0.1231 \\
$0.83217 \ldots$ \\
$0.26598 \ldots$ \\
$0.44371 \ldots$ \\
$-1.6223 \ldots$ \\
$1.2299 \cdots$
\end{tabular}

.139 .104

$2299 \cdots$
3

Active Commitment

Model

Std. Error

Std. Error

0.6391

0.1951
0.1849

0.1301

0.3326

0.07122

0.244

0.3808

0.3571

efficient

0.97962

$0.3398^{\circ}$

$0.43475^{\circ}$

$-0.1615$

$0.89047^{\text {*** }}$

$0.22559 \cdots$

0.52082 ‥

$-1.6904 \cdots$

$1.1076 \cdots$

0.7061

0.2021

0.1913

0.1367

0.3601

0.07419
0.2556

0.2556

0.3918

0.3661

2.1489 …

0.5178

$-128.5463$

Unit

Coefficients for

Active

Commitment

Model

$-0.24191$

0.083912

0.10736

$-0.039882$

0.055707

0.12861

0.27351

$-0.41744$

0.27351

0.53066

$-128.5463$ 
Teblo 4. Two-Stego Estimation

\begin{tabular}{|c|c|c|c|c|c|c|c|c|c|}
\hline \multirow[b]{2}{*}{ Xaciable } & \multicolumn{2}{|c|}{$\begin{array}{l}\quad 1 \\
\text { Structural Model } \\
\text { Dep. Var } \\
\text { CONTRACT } \\
\text { Method OLS }\end{array}$} & \multicolumn{2}{|c|}{$\begin{array}{l}2 \\
\text { Structural Model } \\
\text { Dep Var CNC } \\
\text { Mothod Probil }\end{array}$} & \multicolumn{2}{|c|}{$\begin{array}{l}3 \\
\text { Reduced Form } \\
\text { Dep Var CNC } \\
\text { Method Probit }\end{array}$} & \multicolumn{3}{|c|}{$\begin{array}{l}4 \\
\text { Unit Coetls lor } \\
\text { Peduced Form } \\
\text { Dep. Var CNC } \\
\text { Method Probn }\end{array}$} \\
\hline & coetticien & Sld Eller & coefticien & Sle. Error & coefticient & Sle_Eues & ceatticiend & - & Sle Eur \\
\hline Constant & $.19179^{\circ}$ & 8471 & .076118 & 0.5883 & 13252 & 11.22 & 34781 & & 2.931 \\
\hline NEW & 025613 & 01375 & 043797. & 0198 & 050705 & 01987 & $0.13308 \cdots$ & & 005157 \\
\hline HISKILLL & 011298 & 0.1339 & $051542 \cdots$ & 01919 & 0.47694 * & 01883 & $0.12518 \cdots$ & & 004906 \\
\hline BATCH & 006523 & 0.09714 & .011261 & 01359 & .01223 & 01303 & .00321 & & 003425 \\
\hline COMPLEX & 025737 & 0.1875 & $093274 \cdots$ & 03582 & $086209 \cdots$ & 0,333 & 022626 . & & 000514 \\
\hline SALES & $016918 \ldots$ & 004883 & $028986 \cdots$ & 00741 & $027737 \ldots$ & 0.07286 & 0072798 & & 0.01837 \\
\hline HIWAGE & -009209 & 01947 & 034531 & 02563 & $044587^{\circ}$ & 02462 & 0.11702 . & & 00647 \\
\hline SHARE & 0.52373 & 02787 & 081775 & 0.3483 & $13226 \cdots$ & 03685 & $034713^{\circ}$ & & 009656 \\
\hline AUTO & 0.027503 & 02681 & $-14662 \cdots$ & 0.3498 & $.17231 \cdots$ & 0.3952 & $.045224 \cdots$ & & 0102 \\
\hline CROA & 32122 & 1249 & & & .1901 & 1652 & .49894 & & 4316 \\
\hline CROASO & $.12256 \cdots$ & 4613 & & & 68069 & 6085 & 17865 & & 159 \\
\hline CONTRACT (EST) & & & $0.37675 \cdots$ & 0.174 & & & & & \\
\hline Adj B-Se & 010053 & & & & & & & & \\
\hline Log-1 & & & -125.23 & & .13259 & & .132 .59 & & \\
\hline
\end{tabular}


Table 5. Nonilinear Estimation. Dep. Vartable: CNC

$\begin{array}{lr}\text { Variable } & \text { Coefficient } \\ \text { NEW } & \\ \text { HISKILL } & 8.704 \\ \text { BATCH } & 0.005 \\ \text { COMPLEX } & 3.05 \\ \text { SALES } & 9.7 \\ \text { HIWAGE } & 5.2 \\ \text { SHARE } & 16.9 \\ \text { CONTRACT } & 0.75 \\ & 0.999 \\ \text { Log-L } & -143.677\end{array}$

